\title{
21. Yüzyılda Türkistan Algısı: Eğitim Fakültesi Öğrencilerinin Perspektifinden Bir Değerlendirme ${ }^{1}$
}

\author{
Burak DELICAN ${ }^{2}$ ve Taha Tuna KAYA ${ }^{3}$
}

$\ddot{O} z$

$\mathrm{Bu}$ araştırmanın temel amacı öğretmen adaylarının Türkistan kavramına yönelik algılarını ortaya koymaktır. Bu amaç doğrultusunda öğretmen adaylarının Türkistan kavramına yönelik algıları nitel bir yaklaşımla incelenmiştir. Kolay ulaşılabilir/uygun örnekleme yöntemiyle araştırmanın çalışma grubu Sivas Cumhuriyet Üniversitesi Eğitim Fakültesi öğrencilerinden olușturulmuştur. Çalıșma grubunda Türkçe, Sınıf, Sosyal Bilgiler, Fen ve Teknoloji, İngilizce ve Okul Öncesi Eğitimi öğretmen adayları yer almaktadır. 111 öğretmen adayı araştırma sürecinde gönüllü olarak görüşlerini belirtmek istemiştir. Açık uçlu görüşme soruları ile öğretmen adaylarının Türkistan kavramına ilişkin görüşleri yazılı olarak alınmıştır. Veri toplama aracı olarak kullanılan yazılı görüşme formu üç bölümde şekillendirilmiştir. İlk Bölümde Türkistan kavramına yönelik bilgilerin değerlendirilmesi amaçlanmıştır. İkinci aşamada öğretmen adaylarının Türkistan'a yönelik metaforik algıları belirlenmiştir. Son aşamada ise çalışma grubunda yer alan öğretmen adaylarına "Türkistan neresidir?" sorusu yöneltilerek harita üzerinde işaretlemeleri istenmiștir. Araștırmanın veri toplama süreci sonunda veriler nitel bir bakıș açısıyla değerlendirilip, öğretmen adaylarının Türkistan kavramına ilişkin algıları fenomenolojik bir yaklaşımla analiz edilmiștir. Sonuç olarak öğretmen adaylarının zihninde Türkistan net olarak bir șema olușturmamaktadır. Buna ek olarak Türkistan kavramına yönelik bilginin düşük düzeyde olduğu ifade edilebilir. Diğer taraftan Türkistan'a yönelik tutumun olumlu yönde olduğu belirlenmiştir.

Anabtar Kelimeler: Türkistan, Öğretmen Adayı, Kavram, Alg1

The Perception of Turkistan in the 21st Century: An Evaluation of the Views of the Students Studying at Faculty of Education

\begin{abstract}
The main aim of this study is to present the perception of teacher candidates to the term Turkistan. In accordance with this purpose, their perception to this term has been qualitatively studied. By using the convenience sampling method, the group was formed of students from Faculty of Education at Sivas Cumhuriyet University. The group involves teacher candidates studying Turkish Language, Primary School, Social Sciences, Science and Technology, English Language and Preschool Teaching. 111 teacher candidates volunteered to express their opinions during the study. Their opinions on the term Turkistan have been taken in written by using open-ended interview questions. Used as the data collection tool, the written interview form was structured in three sections. At the first section, it was aimed to evaluate the knowledge about the term Turkistan. At the second phrase, teacher candidates' metaphorical perception about the term was determined. At the last section, the question "Where is Turkistan?" was asked to the candidates and they were expected to mark on the map. After the data collection process of the study, the data were evaluated in a qualitative point of view and their perception about the term was analyzed with a phenomenological approach. Accordingly, the candidates' perception about the term Turkistan was analyzed with the content analysis method. The opinions expressed were classified under notional categories and the correlation between the socio-demographic factors and the category occurred was interrogated. As a result, Turkistan is not clearly imaged in the minds of the teacher candidates. In addition, the knowledge about the term Turkistan can be evaluated as low-level. On the other hand, it was determined that attitude towards Turkistan is favorable.
\end{abstract}

Key Words: Türkistan, Teacher Candidate, Concept, Perception

\section{Atıf İçin / Please Cite As:}

Delican, B, Kaya T.T. (2021). Öndüç hediye: Gaziantep’te yataküstü geleneği ve işlevleri. Manas Sosyal Araşttrmalar Dergisi, 10(3), 1552-1563.

Geliş Tarihi / Received Date: 08.10.2020

Kabul Tarihi / Accepted Date: 19.04.2021

\footnotetext{
${ }^{1}$ Bu araştırmanın bir kısmı 11-12 Nisan 2019 tarihlerinde Hoca Ahmet Yesevi Üniversitesinde gerçekleştirilen Prof. Dr. Fuat Sezgin Anısına Geçmişten Günümüze Türkistan: Tarih, Kültür ve Medeniyet Sempozyumunda sözlü bildiri olarak sunulmuştur. 2 Dr. Öğr. Üyesi. - Tokat Gaziosmanpașa Üniversitesi, Eğitim Fakültesi, burakdelican@gmail.com

(D)ORCID: 0000-0003-3187-0001

${ }^{3}$ Okt. - Belgrad Üniversitesi, Filoloji Fakültesi, tahatuna@gmail.com

(iD ORCID: 0000-0002-8622-5635
} 


\section{Giriş}

Türkistan kuzeyde Sibirya; güneyde Tibet, Hindistan, Afganistan ve İran; doğuda Gobi Çölü ve batıda Hazar Denizine uzanan coğrafi bölge olarak tanımlanmaktadır. Bu sözcügün ilk olarak İranlı coğrafyacılar tarafindan 'Türklerin yaşadığı yer' anlamında, bölgeyi tarif etmek için kullanıldığı düşünülmektedir. Tarihî kaynaklara göre bu alanın adı 19. yüzyıl ortalarına kadar Türkistan'dır (Taşağıl, 2012, s. 557; Türkistan, 2019, s. 2). Bu temel anlamının dişında günümüzde Türkistan sözcüğü ayrıca iki farklı alan için de kullanılmaktadır. Bunların ilki Kazakistan'ın güneyinde Yesi adıyla da bilinen şehirdir. Bu şehir tarihte Şavgar, Yesi, Hazret ve Türkistan adlarılya anılmışır. Son iki adlandırma Türk mutasavvıf Ahmed Yesevî̀ye bağlanmaktadır. Haæret-i Türkistan adıyla bilinen Ahmed Yesevi’nin yaşadığı ve ün kazandığı yer olarak bilinen Yesi şehri, zamanla ona atfedilen bu sıfatlarda anılmıştır (Taşağıl, 2012, s. 556). Kazakistan'da Türkistan şehrinin bulunduğu eyalet de Türkistan Eyaleti olarak adlandırılmaktadır. Sovyet Sosyalist Cumhuriyetler Birliği (SSCB) döneminde 1962 yllına kadar Güney Kazakistan Eyaleti olarak anılan bölge, 1992 yılına kadar Çimkent Eyaleti adını almış, sonrasında ilk adıyla değiştirilmiştir. Son olarak 2018 y1lında bölgenin adı Türkistan Eyaleti olarak değiştirilmiştir ve eyaletin idari merkezi de Çimkent’ten Türkistan şehrine kaydırılmıştır (Astana Times, 2018, s. 1).

Türkistan bir kavram olarak özellikle 20. yüzyllın başlarından itibaren hem SSCB'nin hem de batılı devletlerin üzerinde özellikle durdukları bir kavram olmuştur. Batılı devletler ve SSCB 20. yüzyllın başlarından itibaren bölgeyi Orta Asya olarak adlandırmışlardır (Birsel, 2005, s. 6; Topal, 2014, s. 26). Orta Asya tanımlaması bölgenin Türk kimliği ile özdeşleşmiş yapısını değiştirmek için uygulanan politikaların bir parçası olarak görülmektedir (Birsel, 2005, s. 7; Hayit 1995, s. 55; Köseoğlu, 2014, s. 28; Macit, 2012, s. 23). Diğer taraftan Çin Devletinin Doğu Türkistan'ı Sinkiang (Sincan-Uygur Öžrk Bölgesi) olarak ifade ettiği bilinmektedir (Bahar, 1994, s. 233; Yücel, 2008, s. 11). Türkistan kavramı ile ifade edilmeye çalışılan coğrafi, kültürel ve siyasi olguyu Orta Asya, Sincan-Uygur Özerk Bölgesi gibi kavramların tam olarak karşılamadığı pek çok araştırmacı tarafindan ifade edilmektedir (Amanov, 2007, s. 52; Hayit, 1995, s. 55; Macit, 2012, s. 23). Buna rağmen Rusya, Çin ve batılı devletlerin yürüttüğü bu politikaların Türkistan kavramının günlük hayatta, gazetelerde, dergilerde ve hatta akademik yayınlarda kullanımının azalmasına neden olduğu söylenebilir. 20. Yüzyılın başlarından itibaren bu politikaların bölgenin Türk kimliği ile olan ilişkisini zayıflatmak üzere uygulandığı görülmektedir. Buna karşılık her geçen gün siyasi, ekonomik ve bilimsel olarak Türkistan coğrafyasında daha çok ortak çalışma ve birliktelik görülmektedir.

Türkiye'de Türkistan kavramına yönelik algiyı doğrudan inceleyen çalışmalar kısıtlı olsa da çeşitli araştırmacıların (Alım, 2009; Aksoy ve Karaçalı, 2015; Bay, Alimbekov, Mete, Cücük ve Yokuş, 2017 gibi) Türk Dünyası ve Türk Dünyası Birliği kavramlarına yönelik araştırmalar yürüttügü gözlemlenmektedir. Alım (2009, s. 574) Coğrafya Eğitimi öğrencilerinin Türk Dünyası kavramına yönelik bilgi düzeylerinin yüksek olduğunu ve öğrencilerin Türkiye ile Türk Dünyası arasında yeterince iletişim kurulamamasını bir sorun olarak değerlendirdiklerini belirlemiştir. Aksoy ve Karaçalı (2015, s. 1) ise ilköğretim 7. Sınıf öğrencilerinin Türk Dünyası ile ilgili bilgilerini ders kitaplarından öğrendiklerini ve öğrencilerin yaklaşık \%90'ının bağımsız Türk devletlerinden en çok iki tanesini bilebildiklerini tespit etmiştir. Demirok ve Gülüm (2019, s. 318) tarafindan yapılan araştırmada ise üniversite öğrencilerinin Türk Dünyas1 algis1 değerlendirilmiş ve Türk Dünyasına yönelik siyasal ve sosyo-kültürel algılarının yüksek olduğu ancak ekonomik algılarının düşük olduğu gözlemlenmiştir. Ayrıca örneklemde yer alan eğitim fakültesi öğrencilerinin algılarının daha yüksek olduğu sonucuna ulaşılmıştır. Topal ve Sezer (2016, s. 96) ise üniversite öğrencilerinin Türk Dünyası Coğrafyası algısının oldukça düşük düzeyde olduğunu tespit etmiştir. İlgili literatürde yer alan bu araştırmalar hem ilköğretim hem de üniversite öğrencilerinin Türkistan başta olmak üzere Türk Dünyası ve Türk coğrafyasına yönelik bilgi ve farkındalıklarında çeşitli eksikliklerin olduğuna işaret etmektedir. Özellikle öğretmen yetiştiren kurumlar olarak eğitim fakültesi öğrencilerinin Türk Dünyas1, Türkistan, Türk Coğrafyası gibi kavramlara yönelik bilgi ve farkındalık düzeyleri gelecek nesillerin bu kavramlara ilişkin bilgi ve farkındalıklarını doğrudan etkileyebilecek niteliktedir. Türk Dünyası ve Türk Dünyası Birliği kavramlarının daha anlaşılabilir hale gelmesi için ise Türkistan'ın zihinsel karşıllğının belirginleşmiş olması gerekmektedir. 1900’lerin başlarından itibaren Türkistan kavramı yerine Batı, Çin ve Rusya tarafindan kullanılan Orta Asya, Sincan-Uygur Özerk Bölgesi gibi tanımların Türk dünyası birliği algısının oluşmasına da kavramsal olarak bir engel teşkil ettiği söylenebilir. Öğretmenlerin gelecek nesillerin zihinsel, sosyal ve duygusal gelişimlerine olan etkisi düşünüldüğ̈̈nde, öğretmenlerin başta Türkistan kavramı olmak üzere Türk Dünyası ve Türk Dünyası Birliği kavramlarına ilişkin bilgi ve farkındalık düzeyleri önem arz etmektedir. Bu doğrultuda öğretmenlerin ve öğretmen 
adaylarının Türkistan kavramına yönelik görüşleri gelecek nesillerin Türkistan’a yönelik bakış açılarının şekillenmesinde önemli bir faktör olarak değerlendirilmektedir.

Bu noktadan hareketle araştırmanın temel amacı öğretmen adaylarının Türkistan kavramına yönelik algılarını ortaya koymaktır. Bu temel amaç doğrultusunda aşağıdaki sorulara cevap aranmıştır;

1. Öğretmen adaylarının zihninde Türkistan bir kavram olarak nasıl anlaşılmaktadır?

2. Öğretmen adaylarının Türkistan kavramına yönelik bilgi ve tutumları nasıldır?

3. Öğretmen adaylarının Türkistan'ın sorunları, geleceği ve Türkiye Türkleri ile olan ilişkilerine yönelik görüşleri nelerdir?

4. Öğretmen adaylarının Türkistan kavramına yönelik metaforik algıları nasıldır?

\section{Yöntem}

Bireyin hayatında önemli bir yer tutan öğretmenlerin ve öğretmen adaylarının Türkistan kavramına yönelik görüşleri gelecek nesillerin Türkistan'a yönelik bakış açılarının şekillenmesinde önemli bir faktördür. Bu araştırmada öğretmen adaylarının Türkistan kavramına yönelik algııları nitel bir bakış açısıyla değerlendirilmiştir.

\section{Çalışma Grubu}

Çalışma grubunda Türkistan kavramına yönelik algıları belirlenmek istenen öğretmen adayları yer almıştır. $\mathrm{Bu}$ doğrultuda kolay ulaşılabilir/uygun örnekleme yöntemiyle araştırmanın çalışma grubu Cumhuriyet Üniversitesi Eğitim Fakültesi öğrencilerinden oluşturulmuştur. Çalışma grubunda Türkçe, Sınıf, Sosyal Bilgiler, Fen ve Teknoloji, İngilizce ve Okul Öncesi Eğitimi öğretmen adayları yer almaktadır. Araştırma sürecine 111 öğretmen adayı Türkistan kavramına yönelik algılarını belirtmek üzere gönüllü olarak katılmıştır. Araştırma sürecine katılan 111 öğretmen adayının cevaplarından 100’ünün çalışmaya alınabilir nitelikte olduğu görülmüştür. Bu doğrultuda çalışma grubunda yer alan öğretmen adaylarının branşlara ve cinsiyete göre dağılımı şu şekildedir;

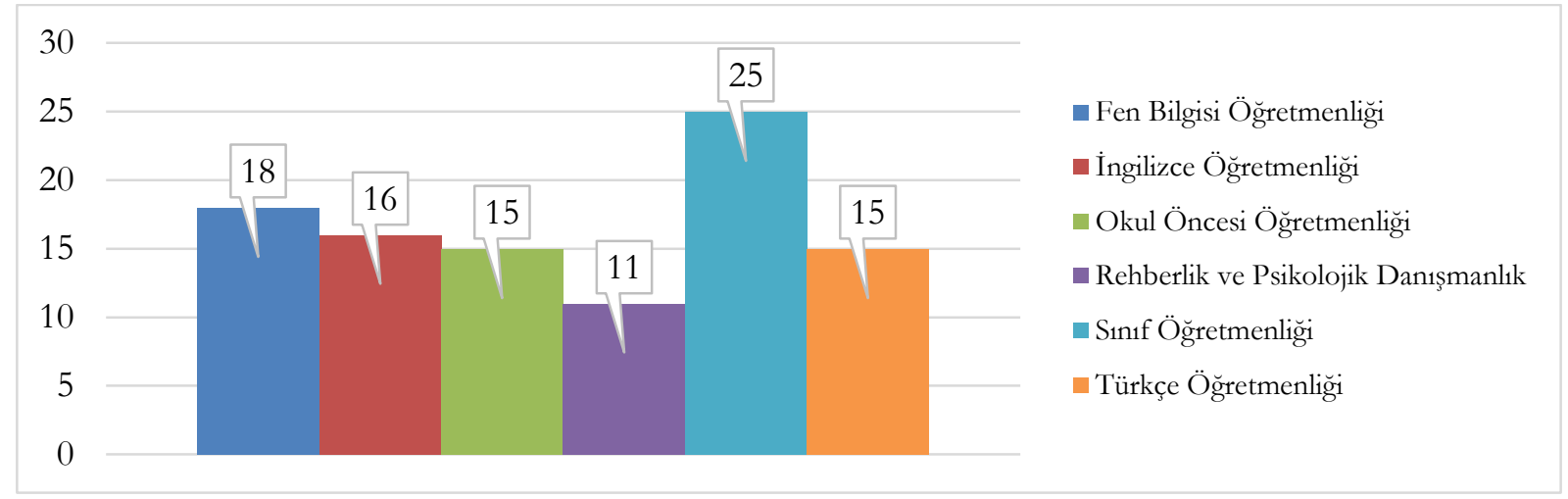

Şekil 1. Öğretmen Adaylarmın Branşlara ve Cinsiyete Göre Dağglımı

Şekil 1'de ifade edildiği üzere çalşma grubunda yer alan öğretmen adaylarının 18’i Fen Bilgisi Öğretmenliği, 16’s1 İngilizce Öğretmenliği, 15’i Okul Öncesi Öğretmenliği, 11'i rehberlik ve psikolojik danışmanlık, 25’i sınıf öğretmenliği ve 15’i Türkçe Öğretmenliği bölümünde yer almaktadır. Cinsiyet açısından incelendiğinde ise çalışma grubunda yer alan öğretmen adaylarının \%30'u kadın \% $\%$ ' i erkektir.

\section{Veri Toplama Araçları}

Araştırmanın veri toplama süreci Şekil 2'de ifade edildiği üzere gerçekleştirilmiştir. Bu süreçte öğretmen adaylarını Türkistan kavramına yönelik algılarını ortaya koymak amacıyla yazılı bir görüşme formu oluşturulmuştur. Oluşturulan yaz1ll görüşme formu üç bölümde şekillendirilmiştir. Görüşmelerin ilk aşamasında "Türkistan ne demektir? Türkistan deyince aklınıza neler geliyor? Türkistan sizin zihninizde neleri çağnıştırıyor? Türkistan kavramıyla bugüne dek nerelerde karşılaştınız? Türkistan'ın en önemli sorunları nelerdir? Batı Türkistan sizin için ne ifade eder? Doğu Türkistan sizin için ne ifade eder? Türkistan hangi devletleri kapsamaktadır? Türkistan'ın sizin için önemi nedir? Türkistan'ın geleceği hakkında neler düşünüyorsunuz? Türkistan kavramını duyduğunuzda aklınıza gelen ilk üç kelime nedir?” sorularına cevap aranmıştır. Görüşmelerin ikinci aşamasında öğretmen adaylarının Türkistan’a yönelik metaforik algıları belirlenmiştir. Öğretmen adaylarından "Benim için Türkistan.........dır. 
Çünkü.

." cümlesini tamamlamaları istenmiştir. Son olarak ise çalısma grubunda yer alan öğretmen adaylarına "Türkistan neresidir?" sorusu yöneltilerek harita üzerinde işaretlemeleri istenmiştir.

\section{Verilerin Analizi}

Araştırmanın veri toplama süreci sonunda veriler nitel bir bakış açısıyla değerlendirilip, öğretmen adaylarının Türkistan kavramına ilişkin algıları fenomenolojik bir yaklaşımla analiz edilmiştir. Bu süreçte içerik analizi tekniğinden faydalanılmıştır. Buradaki amaç kesin ve genellenebilir sonuçlara ulaşmak değil, Türkistan kavramına yönelik algıyı daha iyi tanımaya ve anlamaya yardımcı olacak sonuçlar sağlayacak örnekler, açıklamalar ve yaşantılar ortaya koymaktır. Bu doğrultuda öğretmen adaylarının Türkistan kavramına yönelik algıları içerik analizi tekniği ile analiz edilmiştir. Ortaya çıkan görüşler kavramsal kategoriler altında sınıflandırılmış ve sosyo-demografik değişkenlerle ortaya çıkan kategoriler arasındaki ilişki sorgulanmıştır.

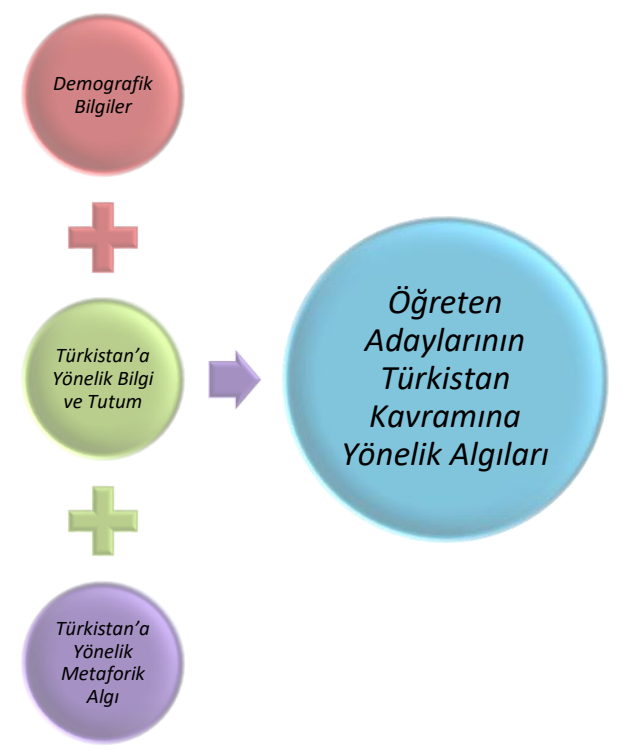

Şekil 2. Araștrmann Veri Toplama Süreci

\section{Bulgular}

Veri analizi sonucunda ulaşılan bulgular araştırmanın temel amacı kapsamında belirlenen alt problemler doğrultusunda ifade edilmiştir. Araştırmanın ilk alt problemi olan "Öğretmen adaylarının zihninde Türkistan bir kavram olarak nasıl anlaşılmaktadır?" sorusuna yönelik ulaşılan bulgular Şekil 3, 4 ve 5 'te ifade edilmiştir.

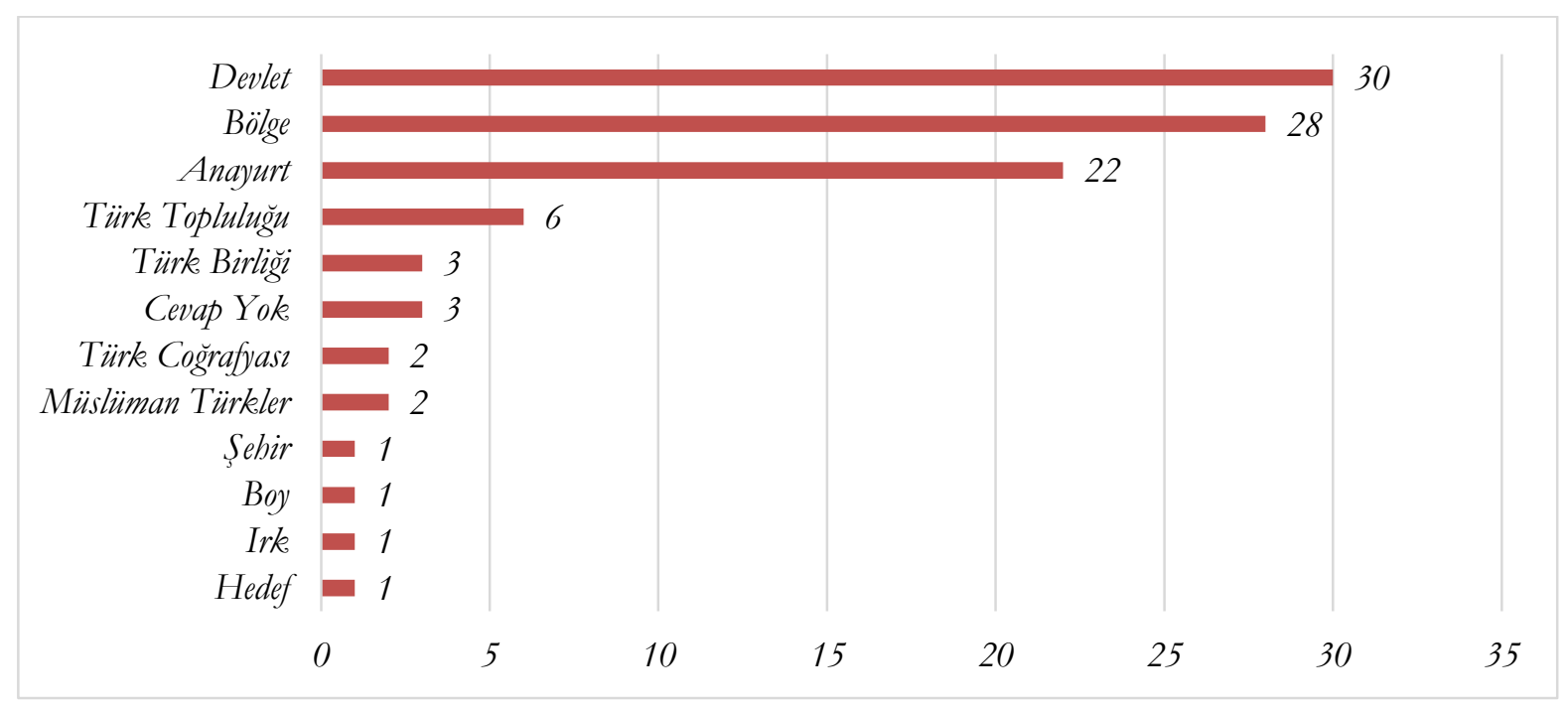


Şekil 3. Öğretmen Adaylarmın "Türkistan kavramın nasıl açıllarsını̨??” Sorusuna İlişkin Görüsleri

Türkistan kavramının öğretmen adaylarının genelinde bir devlet olarak algılandığı ifade edilebilir. Türkistan'1 bir bölge olarak değerlendirenlerin sayısının da yüksek olmasına rağmen genelde Doğu Türkistan bölgesinin zihinlerde canlandığ1 söylenebilir. Öğretmen adayları kısmen Türkistan'1 anayurt olarak ifade etmektedirler. Buna ek olarak Türkistan'1 Türk Topluluğu, Türk Birliği, Türk Coğrafyası, Müslüman Türkler, Şehir, Irk, Hedef olarak değerlendirenler de bulunmaktadır. Öğretmen adaylarının bir kavram olarak Türkistan ile nerede tanıştıklarına ilişkin bulgular Şekil 4'te sunulmuştur.

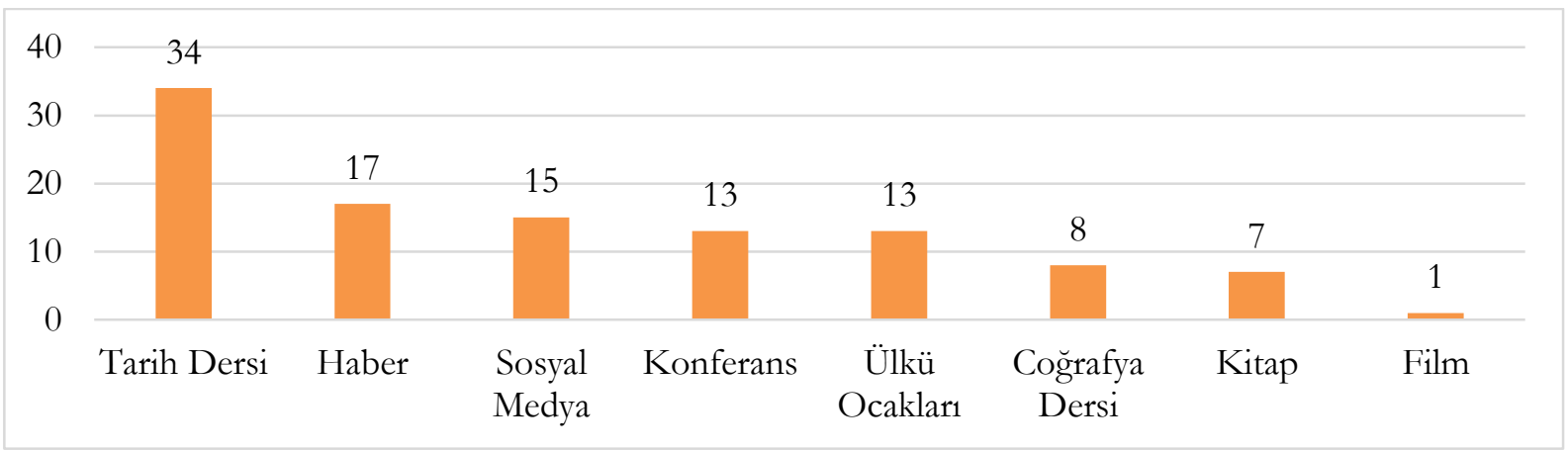

Şekil 4. Öğretmen Adaylarmm Bir Kavram Olarak Türkistan ile Illk Karşılaştıklarn Yerler

Öğretmen adaylarının Türkistan kavramılla ilgili olarak genelde almış oldukları tarih derslerinde ve sosyal medya/haber programlarında karşılaştıkları ifade edilebilir. Buna ek olarak üniversitelerde düzenlenen konferansların ve Ülkü Ocakları Eğitim ve Kültür Vakfının da Türkistan kavramının tanıtılmasında önemli bir etkisinin olduğu ifade edilebilir. Öğretmen adaylarının Türkistan kavramını duyduklarında akıllarına gelen ilk üç kelime ise Şekil 5’te ifade edilmiştir.

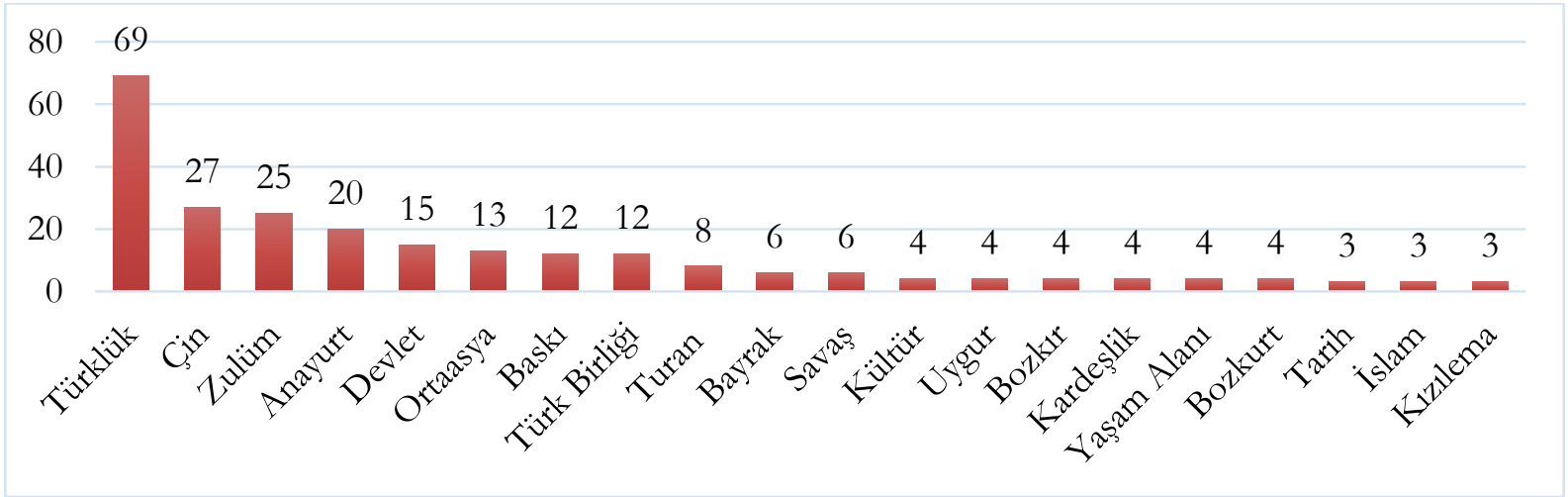

Şekil 5. Öğretmen Adaylarmın Türkistan Kavramın Duyduklarında Akıllarna Gelen İlk Üç Kelime

Şekil 5’te ifade edildiği üzere öğretmen adayları Türkistan kavramını duyduklarında zihinlerinde sıklıkla Türklük belirmektedir. Çin ve Zulüm kavramları ise zihinlerde en çok çağrışım yapan kelimelerdendir. Anayurt, Devlet, Orta Asya, Baskı ve Turan kavramları da pek çok katılımcinın zihninde belirmiştir. Bunlara ek olarak katılımcılardan Türkistan kavramının zihinlerinde Atatürk, Dil, Devlet Bahçeli, Bağımsız̆lk, Milliyetçi Hareket Partisi, Milliyetcilik, Filistin, Kazakistan, Müslüman, Mezopotamya, Sömürge, Esaret, Dostluk, Güc, Huzur, İsgal, Kafkeaslar, Petrol ve Turan kavramlarını çağrıştırdı̆̆ını belirtmişlerdir.

Araştırmanın ikinci alt problemi olan “Öğretmen adaylarının Türkistan kavramına yönelik bilgi ve tutumları nasıldır?” sorusuna yönelik ulaşılan bulgular Şekil 6 ve 7’de ifade edilmiştir.

\begin{tabular}{|c|c|c|c|c|c|}
\hline \multicolumn{6}{|c|}{12} \\
\hline 0 & 20 & 40 & 80 & 100 & 120 \\
\hline & • BİLMIYOR & - KISMEN DOĞRU & " YANLIȘ & - DOĞRU & \\
\hline
\end{tabular}

Şekil 6. Öğretmen Adaylarmın Siyasi Harita Üz̧erinden Türkistan Coğrafyasım Tanımlamalar 
Şekil 6'da ifade edildiği üzere çalışma grubunda yer alan öğretmen adaylarının siyasi harita üzerinden Türkistan coğrafyasını tanımlamaları genel olarak hatalıdır. Çalışma grubunda yer alan öğretmenlerin sadece 3'ü Türkistan coğrafyasını doğru tanımlamışlardır. 50’i öğretmen adayı Türkistan coğrafyasını kısmen doğru tanımlamıştır. 35 öğretmen adayı ise tamamen hatalı tanımlamıştır. 12 öğretmen adayı ise bilgisinin olmadığını belirtmiştir. Öğretmen adaylarının Türkistan coğrafyasını tanımlamalarına yönelik örnek ifadeleri şu şekildedir;

Ö12: Türkmenistan Tacikistan, Özbekistan, Kurgızistan, Çin Halk Cumburiyeti (Doğu Türkistan)

Ö25: Türkistan tek bir devlettir. Basska devletleri içermez:

Ö85: Gürcistan, Türkmenistan.

Ö96: Türk Islam devletlerini kapsamaktadr. devletler.

Ö72: Türk soyundan gelenlerin oluşturduğu ve Atatürk'ïn deyimiyle kendini Türk bissedenlerin oluşturduğu tüm

Çalışma grubunda yer alan öğretmen adaylarının Türkistan kavramının önemine ilişkin görüşleri Şekil 7'de sunulmuştur.

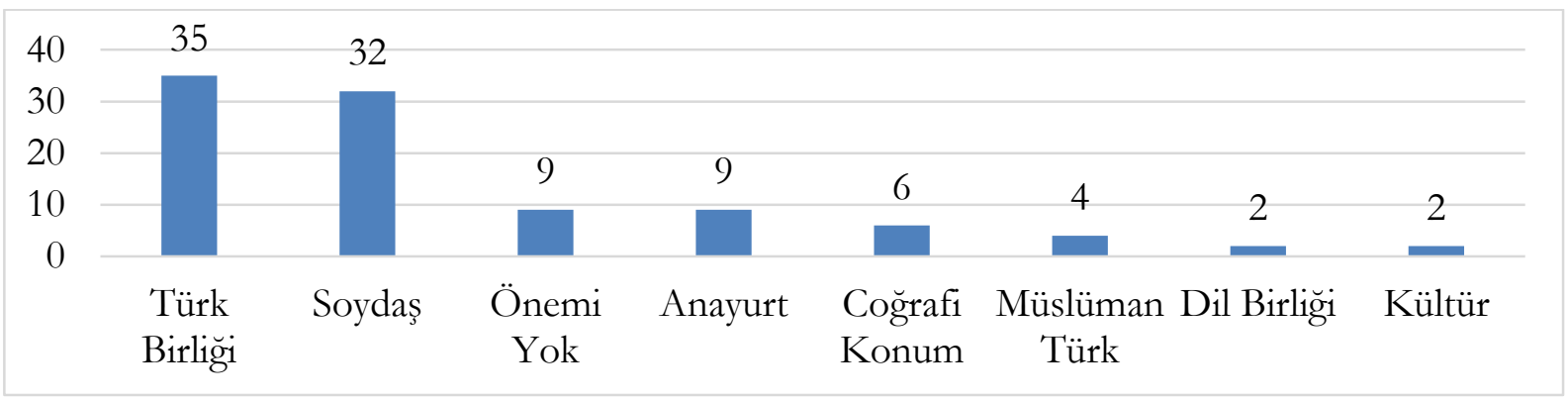

Şekil 7. Ögrretmen Adaylarmm Türkistan Kavrammmn Önemine Illişkin Görüsleri

Çalışma grubunda yer alan öğretmen adaylarının Türkistan’ı Türk Birliği, Soydaşlık, Anayurt, Coğrafi Konum, Müslüman-Türk, Dil Birliği ve Kültür açısından önemli görmektedirler. Buna ek olarak çalışma grubunda yer alan öğretmen adaylarının yaklaşık \%9'u Türkistan kavramının kendilerinin için bir önem ifade etmediğini belirtmişlerdir. Öğretmen adaylarının Türkistan kavramının önemine ilişkin örnek ifadeleri şu şekildedir;

Ö15: Konustuğum dille anlaşabileceăgim insanlar.

Ö63: Türksenin farkh şekilde konusulmasi. Her ülke kendine göre dili değistiriyor. Kendine göre uyarlyor. Türkşe'nin nasıl evrim geçirdiğini gözlemleme imkânmm» var.

Ö56: Bir önemi yok, orda yaşamiyorum

Ö65: Her seyden ziyade önce insan; sonra Müslüman Türk olmalar.

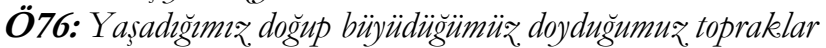

Ö83: Hep beraber bir bayrak altunda toplanmamızın önemli olduğunu görïyorum.

Ö91: Bulunduğu coğrafya nedeniyle önemlidir.

Araştırmanın üçüncü alt problemi olan “Öğretmen adaylarının Türkistan'ın sorunlanı, geleceği ve Türkiye Türkleri ile olan ilişkilerine yönelik görüşleri nelerdir?” sorusuna yönelik ulaşılan bulgular Şekil 8, 9 ve 10 'da ifade edilmiştir.

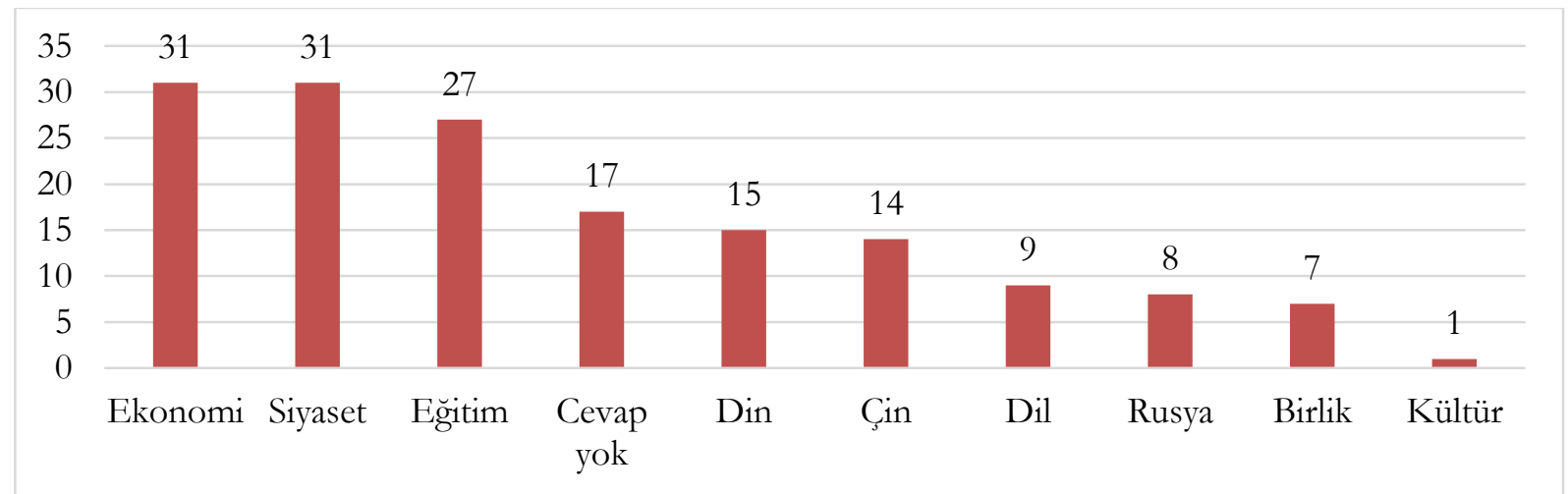


Şekil 8. Ögretmen Adaylarmmn Türkistan'ın Başlıca Sorunlarma İlişkkin Görïsleri

Şekil 8 incelendiğinde öğretmen adayları Türkistan'ın başlıca sorunlarını Ekonomi, Siyaset, Eğitim, Din, Cin, Dil, Rusya ve Kültür başlıkları altında açıklamaktadır. Çalışma grubunda yer alan öğretmenlerin yaklaşık \%17'si ise bu soruya cevap verememişlerdir. Öğretmen adaylarının Türkistan'ın başlıca sorunlarına ilişkin örnek ifadeleri şu şekildedir;

- $A B D$ ve Çin'in verdiği ekonomik zarar.

- Eğitim sijaset ve ekonomi sorunlar vardir. Dışa bağıml balde olduklarndan ve askerí açıdan zayıf olduklar için Çin baskisı ve zulmü devam etmektedir.

- Maalesef siyasi sorunlar, bölge genel olarak Rus bakimiyetinde.

- Ekonomik anlamda kendilerini geliștirememek. Bilimde ilerleme kaydederken var olan șeylerle yetinmek. Mevcut bilim ve buluslarn bir adim öncesine geçememek. Ë̈itimin yetersizliğinden öte kalitesiąliğinin olması.

- Türk aleminde birlik olmamass.

- Yillarca Ruslarn ve Cinlilerin asimile çabalar. Hep bir ezilmislik ve Türkliü̈ünü yasayamayan zorla dillerinden dinlerinden etmek istiyorlar.

Şekil 9’da öğretmen adaylarının Türkistan'ın geleceği hakkındaki görüşleri ifade edilmiştir.

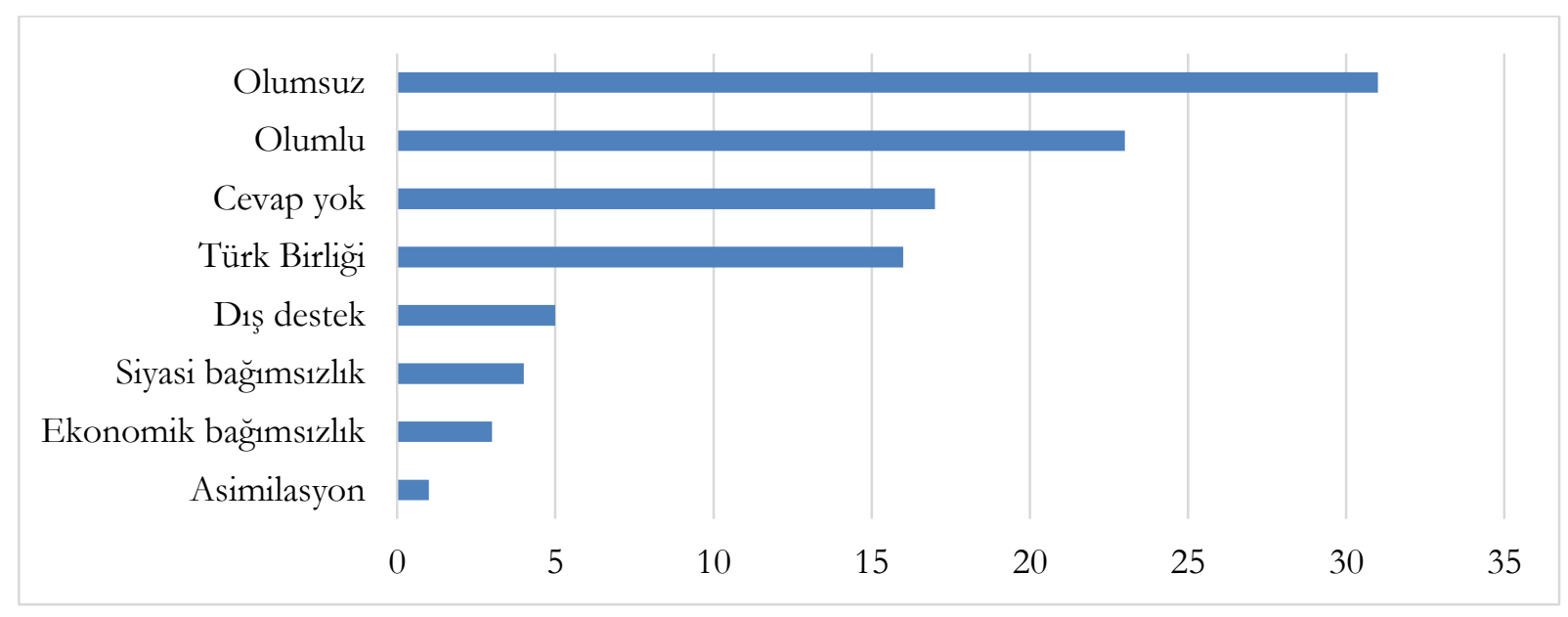

Şekil 9. Öğretmen Adaylarmmn Türkistan'ın Geleceğ̈i Hakekndaki Görüsleri

Çalışma grubunda yer alan öğretmen adaylarının çoğunluğu Türkistan'ın olumsuz bir geleceğe sahip olduğunu düşünmektedir. Türkistan'ın geleceği ile ilgili herhangi bir görüsse sahip olmayanların oranı ise yaklaşık \%17'dir. Bu duruma ek olarak Türkistan'n geleceği ile ilgili olarak Türk Birliğini oluşturabileceği, Dış Desteğe ihtiyaç duyduğu, Siyasi ve Ekonomik Bağımsızlık elde edebileceği ve Asimilasyon ile karşı karşıya kalabileceğini de ifade edenler bulunmaktadır. Öğretmen adaylarının Türkistan'ın geleceğine ilişkin örnek ifadeleri şu şekildedir;

- Cin'in baskecr tavirlar devam edecektir. Zorla dinlerini ve dillerini değğstirmeye zorlayacaktır.

- Bağmsız olarak devam ederler. Dil ve kültürlerini koruyabilirler ancak ekonomik olarak yeraltı kaynaklarn bitecek ekonomik çöküntü yaşayacaklar.

- Yeni kurulmus ülkeler olmasindan dolay gelismeye açlktır özellikle Kazakistan'ın Bilge lideri Nursultan Nazarbayev sayesinde gelismesi ve büyümesine oldukca umutluyum.

- İdareyi kendi ellerine alh zulme ve binlerce ölen insann ölümüne dur diyeceklerine inanyyorum.

- Ekonomik açıdan oldukça iyi gelissiyor. Her gegsen gün büyük Türk birlikteliği için daha Umut verici admmlar atllyor. Cok parlak görïyorum.

- Eğer gerekli yardim yapılmazsa zamanla asimile olarak yok olacaklarm dïssïnüyorum.

- Türkiye gelistikęe bu devletlerinde geliseceğine inanyyorum

- Oradaki işkencelere karşı milli bir uyanıs gerekli

- Bağımsıžluğm ilan edecek

Öğretmen adaylarının Türkistan ile Türkiye Türkleri arasındaki ilişkiye yönelik görüşleri Şekil 10 'da ifade edilmiştir. 


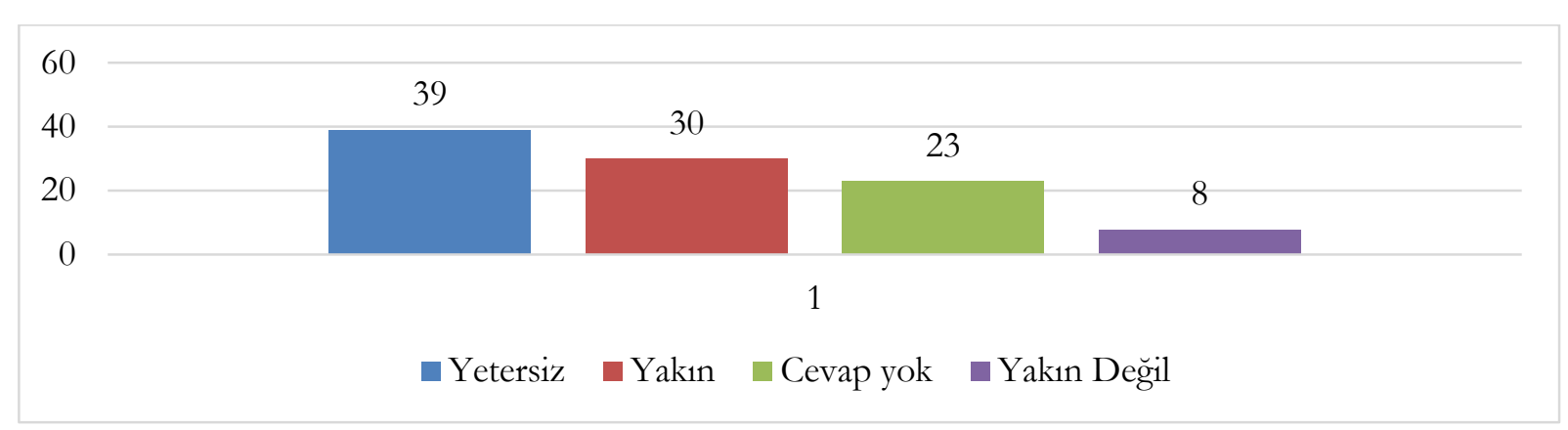

Şekil 10. Öğretmen Adaylarmm Türkistan ile Türkiye Türkleri Arasndaki İlişkiye Yönelike Görüsleri

Çalışma grubunda yer alan öğretmen adaylarının \%39’u Türkistan Türkleri ile Türkiye Türkleri arasındaki ilişkiyi yetersiz olarak değerlendirmektedir. Öğretmen adaylarının \%30’u Türkistan Türkleri ile Türkiye Türklerinin yakın ilişkide olduğunu ifade etmektedir. Öğretmen adaylarının \%23’ü ise Türkistan Türkleri ile Türkiye Türkleri arasındaki ilişkiyi değerlendirmeye yönelik herhangi bir görüşte bulunamamışlardır. Öğretmen adaylarının Türkistan Türkleri ile Türkiye Türkleri arasındaki ilişkiye yönelik görüşlerini şu şekillerde ifade etmişlerdir;

- Türkiye'ye, Türkistan'a yardm edecek kadar firsat vermemeye çalssyorlar. Ekonomi illeti yü̈zünden Türkiye yeteri kadar duruma müdabale edemiyor.

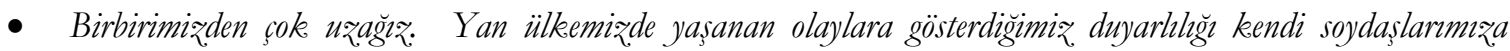
göstermiyoruz: Türk ırkı soyuna sahip çlkmalddr.

- Ortak sosyo kültürel özelliklere sabip iki ayrn coğrafyada yaşayan tek bir milletiz.

- Türkiye Türkleri Türkistan Türklerine karşı duyarl ve sahiplenici bir tutum içindedir.

- Türkiye batı uygarlkklarna daba yakın bir konumda olduğu için kültür bağlaminda ayn konumda değil bana göre, aym zamanda Türkistan Türklerinin bağımsı hlğg yakın tarih olduğu için sömürgesi altunda olduğu ülkelerin kültür siyaset din dil ve ekonomisine benzer niteliğe sabipler

- Her iki ülkede de Türkler olsa da birçok farkhliğmmı var.

Araştırmanın dördüncü alt problemi olan "Öğretmen adaylarının Türkistan kavramına yönelik metaforik algıları nasıldır?” sorusuna yönelik ulaşılan bulgular Şekil 11'de ifade edilmiştir.

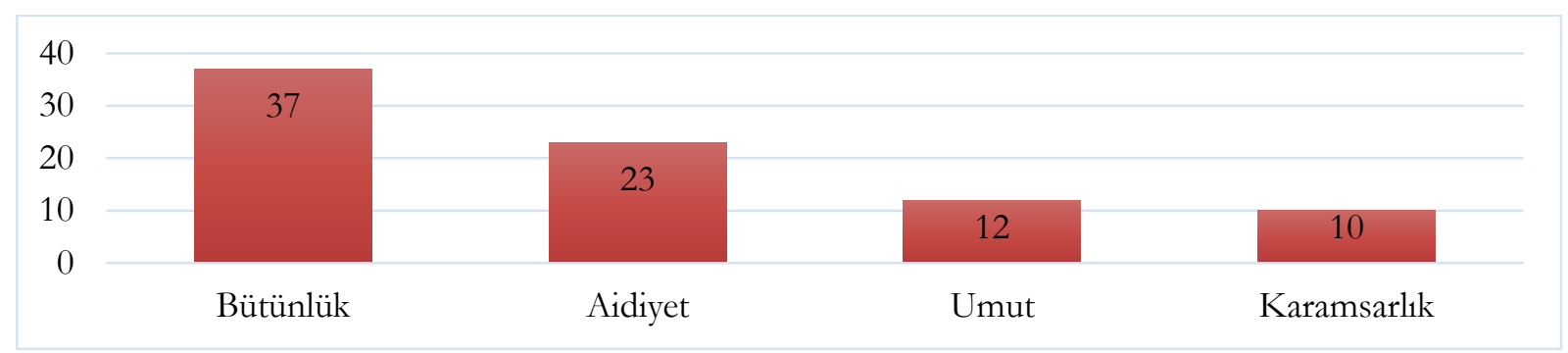

Şekil 11. Öğretmen Adaylarının Türkistan Kavramına Yönelik Metaforik Algılanı

Öğretmen adaylarının Türkistan kavramına yönelik algıları Bütünlük, Aidiyet, Umut ve Karamsarlık temaları alında toplanmaktadır. Öğretmen adaylarının Türkistan kavramına yönelik algılarının bütünlük temasına ait metaforları aşağıdaki gibidir;

- Türkistan ağac gibidir çünkü Ağaç dalları birbirine bir gövde ile bağlanır bu gövde kültürdür.

- Türkistan aym çiçek farklı renk gibidir çünkü Türklüklerini bizim gibi rahat yaşayamıyorlar.

- Türkistan Çınar gibidir çünkü tarihi bir çınar kadar eski ve sağlamdır

- Türkistan Deniz gibidir çünkü denizde var olan varlıklara balık diyoruz ama hepsi farklı özellikte ve isimde, oradaki Türkler de böyle Türk diyoruz ama dini dili vs. özellikleri farklı

- Türkistan Evlenen erkek çocuk gibidir çünkü her ne kadar eşinin kışkırtmalarına gelip kafası karışsa da ailesinden özünden kopamaz.

- Türkistan Kardeş gibidir çünkü Aynı dil ve aynı dini paylaşıyoruz.

- Türkistan El gibidir çünkü parmaklar birleştiğinde bir yumruk kadar güçlü olabilirken parmaklar ayrı hareket ettiğinde güçsüz bir hale gelirler. 

gibidir;

Öğretmen adaylarının Türkistan kavramına yönelik algılarının aidiyet temasına ait metaforları aşağıdaki

- Türkistan Anne gibidir çünkü herkesi tek çatı altında toplar. Bütün zorluklara, acılara rağmen bir arada tutar. O çatı altında herkes bir bütündür ne parçalanabilirler ne de birbirinden ayrılabilirler.

- Türkistan Ev gibidir çünkü Sadece Türkler ve kendisini Türk hissedenlerin olduğu huzur bulduğum yer gibi olur.

- Türkistan Evlat gibidir çünkü Canı yansa canımız yanar.

- Türkistan Vatan gibidir çünkü Bir zamanlar atalarım orada yaşıyordu. Anadolu'da da olsam bir yanım orada. Hiç görmediğim topraklara ve insanlara özlem duyuyorum.

- Türkistan Memleket gibidir çünkü İnsanları bizim insanımızdır

- Türkistan Çocuk gibidir çünkü Bizim Ülkü’müz, değerlerimizle bezendiği, örnek alınan bir ülke olduğumuz için

- Türkistan Kök gibidir çünkü Geldiğimiz yeri coğrafyayı kökü temsil eder.

Öğretmen adaylarının Türkistan kavramına yönelik algılarının umut temasına ait metaforları aşağıdaki gibidir;

- Türkistan Buğday otu gibidir çünkü üstünde bir güneş vardır. Bu güneş zulüm güneşidir. Bu güneşin altında kasıp kavrulur ama zamanı geldiğinde tane tane buğdaylarını verecektir.

- Türkistan Sardunya gibidir çünkü Sadece Türkler ve kendisini Türk hissedenlerin olduğu huzur bulduğum yer gibi olur.

- Türkistan Demir gibidir çünkü güçlü dirençli ve inançlarına sıkı sıkıya bağlıdır.

- Türkistan Kı̨ılelma gibidir çünkü Bütün Türklerin bir arada hoşgörü ile yaşaması gerektiğine inaniyorum

- Türkistan Sessiz Bozkurt gibidir çünkü damarlarındaki gücü keşfetmeyi bekliyor.

- Türkistan Tomurcuk gibidir çünkü bir gün açacak elbet..

- Türkistan Uyanıs gibidir çünkü Türkistan'a yapılan haksızlık karşısında tüm Müslümanlar ve Türkler sessiz kalmayacak ve uykudan uyanarak bu duruma bir son verecektir.

Öğretmen adaylarının Türkistan kavramına yönelik algılarının Karamsarlık temasına ait metaforları aşağıdaki gibidir;

- Türkistan Kanser hastası gibidir çünkü içten içe acı zulüm çekmektedir.

- Türkistan Karanlık gibidir çünkü özellikle Doğu Türkistan da yaşanan tüm üzücü olaylar karanlık bir gün gibi insanların üzerine çökmüştür.

- Türkistan Kurumuş Bir Çiçek gibidir çünkü var ama etkisi yok. Gücü yok. Eski haline dönmesi çok zor.

- Türkistan Suçsuz Bir Mabkûm gibidir çünkü Çinliler oradaki Müslümanların ellerini kollarını bağlamış tutsak etmişlerdir.

- Türkistan Yara gibidir çünkü Bazı sıkıntılardan halen kurtulamamışlardır. Dış devletlerin baskısıyla zulüm ve işkence yapılmaktadır. Özellikle Doğu Türkistan olayları günümüze damga vurmuştur.

- Türkistan Mąlum gibidir çünkü Orta Asya devletlerinden baskı görüyor.

\section{Tartışma, Sonuç ve Öneriler}

$\mathrm{Bu}$ araştırmada öğretmen adaylarının Türkistan kavramına yönelik betimlenmiştir. Araştırma sonuçlarına göre öğretmen adaylarının zihninde Türkistan bir kavram olarak net bir karşılık bulmamaktadır. Öğretmen adaylarının geneli Türkistan’ı bir devlet olarak düşünmektedir. Bunun yanında boy, ırk, Türk birliği olarak düşünenler de bulunmaktadır. Bir bölge olarak düşünenlerde ise Türkistan genel olarak Doğu Türkistan'ı çağrıştırmaktadır. Türkistan kavramının öğretmen adayının belleğindeki Türkmenistan adlı ülke ile karıştırılması, çevreden Türkistan ile ilgili en çok duydukları kavramın Doğu Türkistan olması ve kavramsal düşünme becerilerinin yeterli olmaması bu yanlış algıların sebepleri olarak sıralanabilir. Diğer taraftan Türkistan ifadesinin aynı zamanda Kazakistan’da bir şehir adı olması, bununla da kalmayıp 2018 yılında Güney Kazakistan Eyaletinin adının değiştirilerek Türkistan Eyaleti yapılması, halihazırda zihinlerde net olarak şekillenmeyen Türkistan algısının daha çok karıştırılmasına, zarar görmesine ve kavramın dar bir alana sıkışmasına sebep olmuştur. 
Öğretmen adaylarının zihninde Türkistan en yoğun olarak Türklük, Çin ve zulüm kavramlarını çağrıştırmaktadır. Ayrıca öğretmen adaylarının önemli bir kısmı (\%58) Türkistan kavramını ilk kez okul ve kitap dışında duyduklarını söylemektedir. Bu sebeple Doğu Türkistan'da Uygur Türklerinin maruz kaldığ1 olaylarla ilgili haberlerin bu algıyı oluşturmasında etkili olduğu açıktır. Ancak diğer taraftan Türkistan kavramına yönelik bilgi düzeyinin de oldukça düşük olduğu söylenebilir. Öğretmen adaylarının Türkistan kavramına yönelik açıklamalara bakıldığında pek çoğunun aklında Doğu Türkistan'ın belirdiği (\%50) ve büyük bir kısmının yanlış coğrafi bölgeleri ifade ettiği (\%35) görülmektedir. Öğretmen adayları arasında bir coğrafi bölge olarak Türkistan'ı tanımlayabilenlerin oranı \%3’tür. Bu sonuç öğretmen adaylarının Türkistan kavramına yönelik bilgi düzeylerinin oldukça düşük olduğu şeklinde yorumlanabilir.

Öğretmen adaylarının Türkistan kavramına yönelik bilgi düzeylerinin düşük olmasına rağmen Türkistan’a önem verdikleri de görülmektedir. Öğretmen adaylarının \%35’i Türk Birliğinin oluşturulmas1, \%32'si de soydaş olunması nedeniyle Türkistan'a önem verdiklerini belirtmişlerdir. Öğretmen adaylarının \%10’u ise Türkistan'ın onlar için bir önem teşkil etmediğini ifade etmiştir. Kültürel bir coğrafya birliği olan Türkistan'ın gelecekte sosyal, ekonomik veya siyasi bir birlik olma ihtimalinin öğretmen adaylarının zihninde yer aldığı görülmektedir.

Öğretmen adayları Türkistan'ın başlıca sorunlarını ekonomi, siyaset, eğitim ve din başlıkları altında ifade etmektedir. Öğretmen adaylarının Türkistan'ın sorunlarına yönelik algılarında Doğu Türkistan bölgesinin önemli bir etkisi olduğu ifade edilebilir. Öğretmen adayları Türkistan bölgesinde Rusya ve Çin baskısı altında ekonomik, siyasi ve dinî güçlükler yaşandığını düşünmektedir. Bu baskılardan dolayı da Türkistan geleceğine yönelik olumsuz bir bakış açısı geliştirdikleri söylenebilir. Buna ek olarak cevaplarda ön plana çıkan ekonomi, siyaset ve eğitim gibi kavramları Türkistan bölgesinde yer alan ülkelerin de gelişmek için önem verdiği başlıklardır.

Öğretmen adayların çoğunluğu (\%39) Türkistan Türkleri ile Türkiye Türkleri arasındaki ilişkiyi yetersiz olarak değerlendirmektedir. İlişkilerin geliştirilmesi için yeni adımlar birliktelikler oluşturulması gerektiğini belirtmektedirler. Diğger taraftan yakın ilişkide olduğunu ifade edenler (\%30) rrk, kültür, dil ve din açısından bütünlük taşındığını söylemektedirler. Öğretmen adaylarının \%10’u ise Türkistan Türkleri ile Türkiye Türklerinin birbirlerine yakın topluluklar olduklarını düşünmemektedir. Diğer taraftan \%23’lük kesim Türkistan Türkleri ile Türkiye Türkleri arasındaki ilişki hakkında fikirlerinin olmadığını belirtmişlerdir.

Öğretmen adaylanının Türkistan kavramına yönelik metaforik algıları incelendiğinde öğretmen adaylarının Türkistan’a yönelik olumlu tutum geliştirdikleri ifade edilebilir. Öğretmen adaylanı Türkistan’1 sahiplenirken bu durumu Bütünlük, Aidiyet, Umut ve Karamsarlık kategorileri altında ifade etmişlerdir. Öğretmen adaylarının bu kategorileri belirtmesinde önceki cevaplarındaki Türk birliği, anayurt gibi olumlu kavramların etkili olduğu görülmekte olup arka sıralarda gelen karamsarlık kategorisi yine Doğu Türkistan kavramıyla ilişkilendirilebilir.

Gelecek nesillerin Türkistan algısının doğru bir şekilde gelişmesinde öğretmenlerin önemli bir rolü bulunmaktadır. $\mathrm{Bu}$ nedenle eğitim fakültelerinin programları oluşturulurken program geliştiricilerin bu konu üzerinde dikkat olmaları önerilmektedir. Gerek seçmeli olarak açılabilecek Türkistan ile ilgili derslerle gerek mevcut derslerin müfredatına karşılaştırmalı konular dahil edilerek bu algının gelecek kuşaklara doğru aktarımı sağlanabilir. Diğer fakültelerde öğrenim görenlerin de çalışmanın sonucunda çıkan benzer algılara sahip olabileceği düşünülerek alanlarılla ilgili olarak Türkistan başlıklı seçmeli dersler (Türk Dünyası Sineması, Edebiyat1 vb) sunulabilir.

Türkistan kavramına yönelik bilgi düzeylerinin düşük olmasına rağmen öğretmen adaylarının bu kavrama yönelik olumlu tutum geliştirmeleri için Türkistan coğrafyası ile Türkiye arasında hareketlilik sağlanması etkili olabilir. Yükseköğretim Kurumunun Mevlâna Programı, Avrupa Birliğinin Erasmus Ortak Ülkeler Projeleri ve TİKA'nın projelerinde öncelik Türkistan bölgesi ülkelerine verilebilir. Karşlıklı öğrenci ve öğretici hareketliliğiyle Türkiye'deki Türkistan algılarının üst düzeye çıkması sağlanabilir. Böylelikle akademik ve bilimsel hareketliliklerle başlayan yakınlaşma ve birliktelik daha sonra toplumsal olarak kendini gösterebilir.

Çalışmanın sonucunda öğretmen adaylarının başlıca sorun olarak değerlendirdiği ekonomi, siyaset ve eğitim gibi başlıklar aynı zamanda mevcut Türkiye-Türkistan ilişkilerinin kilit taşlarıdır. Yukarıda bahsi geçen eğitsel iş birliklerine ek olarak ekonomik ve siyasi ortak çalışmalar sıklaştırılarak bu sorunların aşılması kolaylaştırabilir. 
Çalışmadaki cevaplardan öğretmen adaylarının önemli bir kısmının Türkistan algısında medya araçlarının etkisinin ön plana çıktı̆̆ görülmektedir. Bu etkiyi doğru bir şekilde değerlendirerek özellikle sosyal medya araçlarında Türkistan sözcügünü daha görünür kılmak ve kavramı doğru ifadesi ile kullanmak genç kuşaklardaki algı karmaşasını ortadan kaldıracaktır.

\section{Etik Beyan}

"21. Yürynlda Türkistan Algısı: Eğitim Fakültesi Öğrencilerinin Perspektifinden Bir Değerlendirme” başliklı çalışmanın yazım sürecinde bilimsel kurallara, etik ve alıntı kurallarına uyulmuş; toplanan veriler üzerinde herhangi bir tahrifat yapılmamış ve bu çalışma herhangi başka bir akademik yayın ortamına değerlendirme için gönderilmemiştir. Bu araştırmanın verileri 01.01.2020 tarihinden önce toplandığı ve makalenin süreci 2020 yllında başladığından etik kurul kararı zorunluluğu taşımamaktadır.

\section{Kaynakça}

Amanov Ş. (2007). Sovyetler birliğinin dağ̊lmasindan sonra Amerika Birleşik Devletlerinin orta asya politikast (Doktora Tezi). Gazi Üniversitesi Sosyal Bilimler Enstitüsü, Ankara.

Alım, M. (2009). Coğrafya eğitimi öğrencilerinin Türk dünyası algıları (Atatürk Üniversitesi örneği). Uluslararası insan Bilimleri Dergisi, 6(2), 574-586.

Aksoy, B. ve Karaçalı, H. (2015). 7. Sınıf öğrencilerinin zihin haritasında Türk Dünyası algısı. Uluslararası Türk Eğitim Bilimleri Dergisi, 15(4), 1-14.

Astana Times, (2018). Shymkent declared city of national significance, South Kazakhstan region gains new name and administrative centre. Erişim adresi: https://astanatimes.com/2018/06/shymkent-declared-city-of-national-significance-southkazakhstan-region-gains-new-name-and-administrative-centre/

Bahar, H. (1994). Türkistan’n coğrafi konumu ve ilkçağ kaynaklarına göre tarihi. Selçuk Üniversitesi Türkiyat Arasstrmalar Dergisi, 1(1), 233-244.

Bay, E., Alimbekov, A., Mete, M., Cücük, E. ve Yokuş, E. (2017). Türk dünyası birliği algısı. Gą̧ Akademik Bakess, 11(21), 55-85.

Birsel, H. (2005). Küresel gǘs mücadelesinde Türkistan jeopolitïği ve Özbekistan (1991-2005) (Yüksek Lisans Tezi). Süleyman Demirel Üniversitesi Sosyal Bilimler Enstitüsü. Isparta.

Demirok U. ve Gülüm, K. (2019). Üniversite öğrencilerinin Türk dünyası alg1sı. Turan: Stratejile Arasstrmalar Merkeri, 11(43), 72-81.

Hayit, B. (1995). Türkistan devletlerinin millí mücadeleleri taribi. Ankara: Türk Tarih Kurumu Yayınları.

Köseoğlu, T. (2014). Soryetlerin Türkistan dönüstürme siyasetine mubalefet: Yaş Türkistan dergisi (Doktora Tezi). Marmara Üniversitesi Türkiyat Araştırmaları Enstitüsü. İstanbul.

Macit, N. (2012). Orta asya Türk cumhuriyetleri demokrasi kuşağı oluşturma planının/Arap baharının neresinde?. Türk Dünyasi İncelemeleri Dergisi, 12(1), 21-68.

Taşağ1l, A. (2012). Türkistan. Erişim Adresi: https://cdn2.islamansiklopedisi.org.tr/dosya/41/C41013514.pdf

Topal, E. (2014). Üniversite ögrencilerinin Türk dünyası coğrafyasina ilişkin farkendallk dü̈eylerinin belirlenmesi. (Yüksek Lisans Tezi). Uşak Üniversitesi Sosyal Bilimler Enstitüsü. Uşak.

Topal, E. ve Sezer, A. (2016). Üniversite öğrencilerinin türk dünyası coğrafyasına ilişkin farkındalık düzeylerinin belirlenmesi. Marmara Coğrafja Dergisi, (33), 96-113.

Britannica, T. Editors of Encyclopaedia (2020, April 27). Turkistan. Encyclopedia Britannica. https://www.britannica.com/place/Turkistan

Turkestan. (2019). In Britannica encyclopedia. Erişim Adresi: https://www.britannica.com/place/Turkestan

Turkistan. (2019). In Britannica encyclopedia. Erişim Adresi: https://www.britannica.com/place/Turkistan

Yücel, L. (2008). Türkistan üzerinde Cin Halk Cumburiyetinin Amerika Birlesilk Devletleri ve Rusya Federasyonu ile rekabeti. (Yüksek Lisans Tezi). Uşak Üniversitesi Sosyal Bilimler Enstitüsü. Uşak

\section{EXTENDED ABSTRACT}

The main aim of this study is to present the perception of teacher candidates to the term Turkistan. In accordance with this purpose, their perception to this term has been qualitatively studied. Turkistan, also spelled Turkestan, in Asian history, the regions of Central Asia lying between Siberia on the north; Tibet, India, Afghanistan, and Iran on the south; the Gobi (desert) on the east; and the Caspian Sea on the west. It is thought that the term was firstly intended to use by Iranian geographers to indicate the areas inhabited by Turkic peoples.

According to historical sources, the name of this area was Turkistan until the middle of the 19th century. As a concept, Turkestan has been a concept that both the USSR and the western states especially emphasized since the beginning of the 20th century. Western states and the USSR have named the region Central Asia since the beginning of the 20th century. 
The definition of Central Asia is seen as a part of the policies implemented to change the status of the region identified with the Turkish identity. It is seen that these policies have been implemented since the beginning of the 20th century to weaken the relationship of the region with the Turkish identity. On the other hand, more and more collaborative work and unity are seen in the geography of Turkistan every day, politically, economically, and scientifically. When the situation is evaluated from this point of view, the perceptions of future teachers towards the concept of Turkistan are significant.

Opinion on the term Turkistan of the teachers and teacher candidates, who have an important place in an individual's life, is an important factor about the approach of the next generations to the term Turkistan. Therefore, it has been decided that teacher candidates take place in experimental group. By using the convenience sampling method, the group was formed of students from Faculty of Education at Sivas Cumhuriyet University. The group involves teacher candidates studying Turkish Language, Primary School, Social Sciences, Science and Technology, English Language and Preschool Teaching. 111 teacher candidates volunteered to express their opinions during the study. It was observed that 100 of the responses of 111 teacher candidates who participated in the research process were qualified to be included in the study.

Their opinions on the term Turkistan have been taken in written by using open-ended interview questions. Used as the data collection tool, the written interview form was structured in three sections. At the first section, it was aimed to evaluate the knowledge about the term Turkistan and answers were sought for these questions: "What does Turkistan mean? What does come to your mind when it is said 'Turkistan'? What does Turkistan evoke in your mind? Where have you encountered the concept of Turkistan up to now? What are the most important problems of Turkistan? What does West Turkistan mean to you? What does East Turkistan mean to you? Which states does Turkistan cover? What is the importance of Turkestan for you? What do you think about the future of Turkistan? What are the first three words that come to mind when you hear the concept of "Turkistan"? At the second phrase, teacher candidates' metaphorical perception about the term was determined. Teacher candidates were asked to complete this sentence: "According to me, Turkistan is .... . Because ....". At the last section, the question "Where is Turkistan?" was asked to the candidates and they were expected to mark on the map. After the data collection process of the study, the data were evaluated in a qualitative point of view and their perception about the term was analyzed with a phenomenological approach. Accordingly, the candidates' perception about the term Turkistan was analyzed with the content analysis method. The opinions expressed were classified under notional categories and the correlation between the sociodemographic factors and the category occurred was interrogated. As a result, Turkistan is not clearly imaged in the minds of the teacher candidates. Most of the teacher candidates think of Turkistan as a state. In addition, there are also those who consider it as tribe, nation, race, Turkish unity. For those who consider it as a region, Turkistan generally evokes East Turkistan. In the minds of teacher candidates, Turkistan most intensely evokes the concepts of Turkishness, China and persecution. The news about the incidents suffered by Uyghur Turks in East Turkistan is effective in creating this perception. The ratio of the teacher candidates who can define Turkistan as a geographical region is 3\%. This result can be interpreted as their level of knowledge about the concept of Turkistan is quite low. In addition, the knowledge about the term Turkistan can be evaluated as low-level. On the other hand, it was determined that attitude towards Turkistan is favorable. It is also seen that although the teacher candidates' knowledge of the concept of Turkistan is low, they attach importance to Turkistan. 35\% of the teacher candidates stated that they attach importance to Turkistan due to the formation of the Turkish Union and $32 \%$ of them because of their kinship. Teacher candidates express the main problems of Turkistan under the titles of economy, politics, education, and religion. It can be stated that the East Turkistan region has an important effect on the perceptions of the teacher candidates about the problems of Turkestan. Teachers have an important role in the correct development of the perception of Turkistan of future generations. For this purpose, it is recommended that program developers pay attention to this issue while creating the programs of education faculties. Despite the low level of knowledge of teacher candidates on the concept of Turkestan, it can be effective to ensure mobilities, especially academically, between Turkey and Turkestan geography to develop a positive attitude towards this concept. 